\title{
BAX wt Allele
}

National Cancer Institute

\section{Source}

National Cancer Institute. BAX wt Allele. NCI Thesaurus. Code C49368.

Human BAX wild-type allele is located within 19q13.3-q13.4 and is approximately $7 \mathrm{~kb}$ in length. This allele, which encodes apoptosis regulator BAX protein, plays a role in the regulation of the apoptotic program by varying the permeability of the mitochondrial membrane. 